\title{
Atmospheric Deposition of Radionuclides and Major and Trace Elements by Moss Biomonitoring Technique
}

\author{
Sema Erenturk, Sevilay Haciyakupoglu* \\ Energy Institute, Istanbul Technical University, 34469, Maslak, Istanbul, Turkey
}

\author{
Received: 31 March 2017 \\ Accepted: 11 July 2017
}

\begin{abstract}
The present study was undertaken as a survey of radiological and chemical air pollution on both the European and Asian sides of Istanbul, Turkey. In this framework, radionuclide activity concentrations and selected metal amounts in moss samples collected from urban, suburban, industrial, and green zone areas in Istanbul were determined following the moss biomonitoring technique. The activity concentrations in the moss samples vary from 2 to $20 \mathrm{~Bq} / \mathrm{kg}$ for ${ }^{226} \mathrm{Ra}$, from 4 to $23 \mathrm{~Bq} / \mathrm{kg}$ for ${ }^{232} \mathrm{Th}$, and 359 to $2,809 \mathrm{~Bq} / \mathrm{kg}$ for ${ }^{40} \mathrm{~K}$ for both sides of the city. Concentrations of $\mathrm{Al}, \mathrm{As}, \mathrm{Cd}, \mathrm{Cr}, \mathrm{Cu}, \mathrm{Fe}, \mathrm{Hg}, \mathrm{Ni}, \mathrm{Pb}, \mathrm{Sb}, \mathrm{V}$, and $\mathrm{Zn}$ were determined by ICP-ES. Additionally, potential ecological impacts of atmospheric deposition for selected metals based on moss analysis around Istanbul were assessed. Results show that the enrichment factor for the European side was greater than 10 for $\mathrm{Pb}$.
\end{abstract}

Keywords: air pollution, Istanbul, radioactivity moss, heavy metal

\section{Introduction}

Mosses are comparatively more effective at accumulating elements and heavy metals than other plant species. Therefore, moss biomonitoring was used as a complementary technique alongside classic instrumental methods in air pollution detection and control. Also, mosses have been used as bioindicators for terrestrial long-lived radionuclides $\left({ }^{40} \mathrm{~K},{ }^{238} \mathrm{U}\right.$, and $\left.{ }^{232} \mathrm{Th}\right)$ and artificial radionuclides $\left({ }^{137} \mathrm{Cs},{ }^{90} \mathrm{Sr}\right.$, and $\left.{ }^{239+240} \mathrm{Pu}\right)$ in the environment [1-5].

Rapid industrialization in cities and the contributory relationships with the original pollution sources can cause serious environmental problems within cities [6-9]. Istanbul is the most crowded city in Turkey and the fifth most crowded in the world. The present study was conducted as a survey of air pollution on both the European and Asian sides of Istanbul. Moss samples were collected from urban, suburban, industrial, and green zone areas on both the European and Asian sides of Istanbul. Radionuclide activity concentrations and major and trace element amounts in moss samples were determined. Additionally, ecological impacts of atmospheric deposition for selected metals (As, $\mathrm{Cr}, \mathrm{Cu}$, $\mathrm{Ni}, \mathrm{Pb}$, and $\mathrm{Zn}$ ) based on moss analysis around Istanbul was assessed. The enrichment factors of each pollutant and the potential ecological risk index were evaluated. Also, cluster analysis using the Minitab 7.0 program was employed for the obtained data.

*e-mail: haciyakup1@itu.edu.tr 


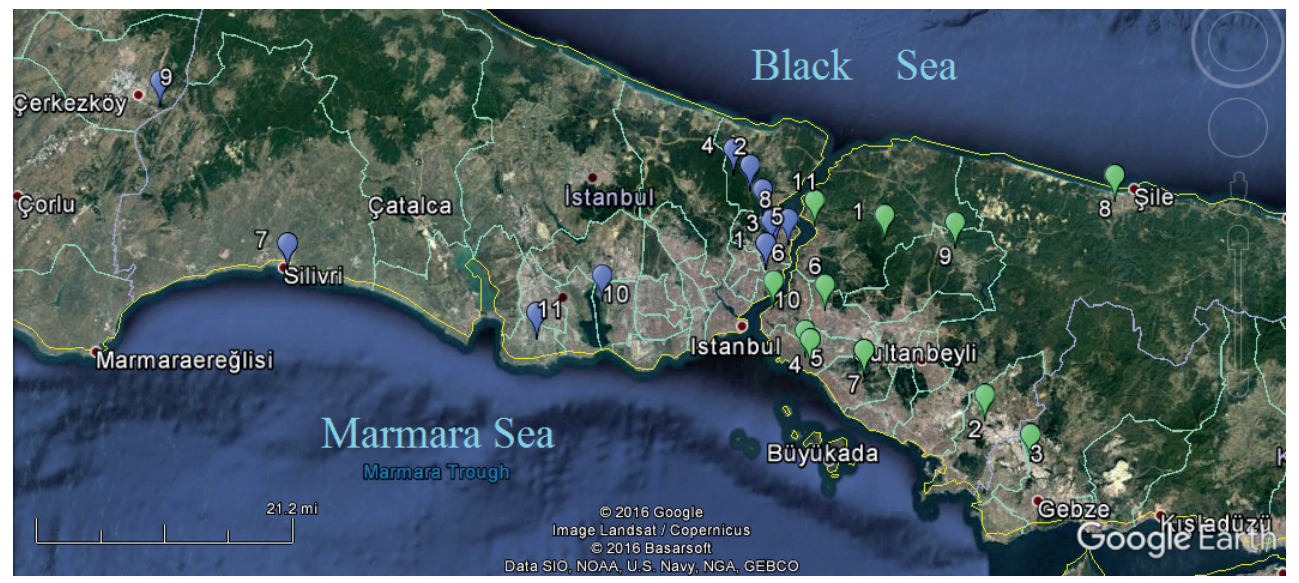

Fig. 1. Sampling sides on the European and Asian side of Istanbul.

\section{Experimental}

\section{Study Area and Moss Sampling}

Istanbul occupies two different continents with one part in Europe and the other in Asia as split by the Bosphorus strait that connects the Black Sea and the Sea of Marmara. Terrestrial moss samples were collected from tree pith on the European side from suburban and green zones, industrial areas, and nuclear plant areas; and on the Asian side from suburban zones, green zones, suburban and green zones, and industrial areas. Fig. 1 shows moss sampling zones, and at least two or three moss samples were collected from all the zones.

\section{Sample Preparation}

Moss samples were carefully cleaned from all dead material and attached litter. Treatment of moss samples to constant weight was applied by drying them at room temperature $\left(25^{\circ} \mathrm{C}\right)$. Non-treated samples were used in metal and radioactivity determination measurements.

Sealed samples were kept aside for about 38 days to achieve radioactive equilibrium. Gamma-ray spectra of samples were measured by the calibrated n-type HPGe detector $(45.7 \%$ efficiency), which was connected to a digital signal processing analyzer (ORTEC DSPEC jr. 2.0) operating with a Gamma Vision-32 spectroscopy program at the statistical confidence level $2 \sigma$ and range $8 \mathrm{~K}$. Quality control for radioactive measurements was applied by certified radioactive volume sources in different densities and shapes.

The metal determinations were performed using ICPES. Microwave digestion was carried out on the moss samples using concentrated $\mathrm{HNO}_{3}$ (Merck, 65\% purity). Concentrations of $\mathrm{Al}, \mathrm{As}, \mathrm{Cd}, \mathrm{Cr}, \mathrm{Cu}, \mathrm{Fe}, \mathrm{Hg}, \mathrm{Ni}, \mathrm{Pb}, \mathrm{Sb}$, $\mathrm{V}$, and $\mathrm{Zn}$ were determined by ICP-ES. Each moss sample was analysed at least two times. Quality control for the elemental analysis results were checked by concentrations of standards.

\section{Results and Discussion}

\section{Radionuclide Deposition on Moss Samples}

The minimum detectable activities were found as $1 \mathrm{~Bq} /$ $\mathrm{kg}$ for ${ }^{226} \mathrm{Ra}$ and for ${ }^{232} \mathrm{Th}$ and $2 \mathrm{~Bq} / \mathrm{kg}$ for ${ }^{40} \mathrm{~K}$ radionuclides in the gamma spectroscopy system. Radioactivity results showed that the activity concentrations in the moss samples vary from 8 to $20 \mathrm{~Bq} / \mathrm{kg}$ for ${ }^{226} \mathrm{Ra}$, from 10 to $23 \mathrm{~Bq} / \mathrm{kg}$ for ${ }^{232} \mathrm{Th}$, and from 823 to $2,809 \mathrm{~Bq} / \mathrm{kg}$ for ${ }^{40} \mathrm{~K}$ on the European side (Fig. 2a), and varied from 2 to
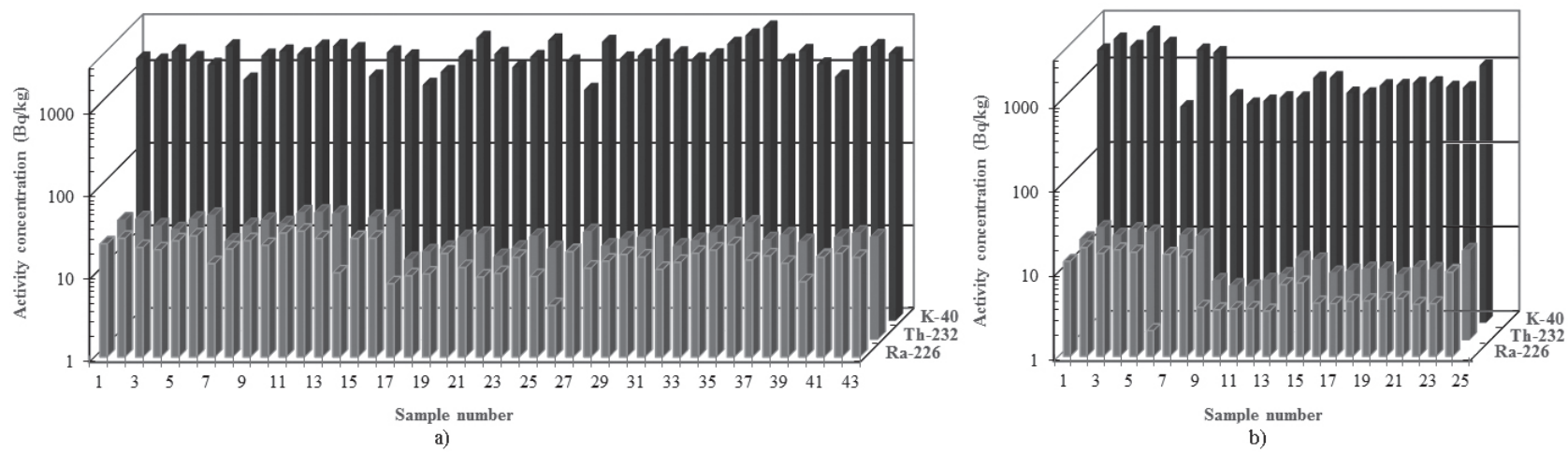

Fig. 2. Radioactivity concentration results for a) European and b) Asian sides of Istanbul. 

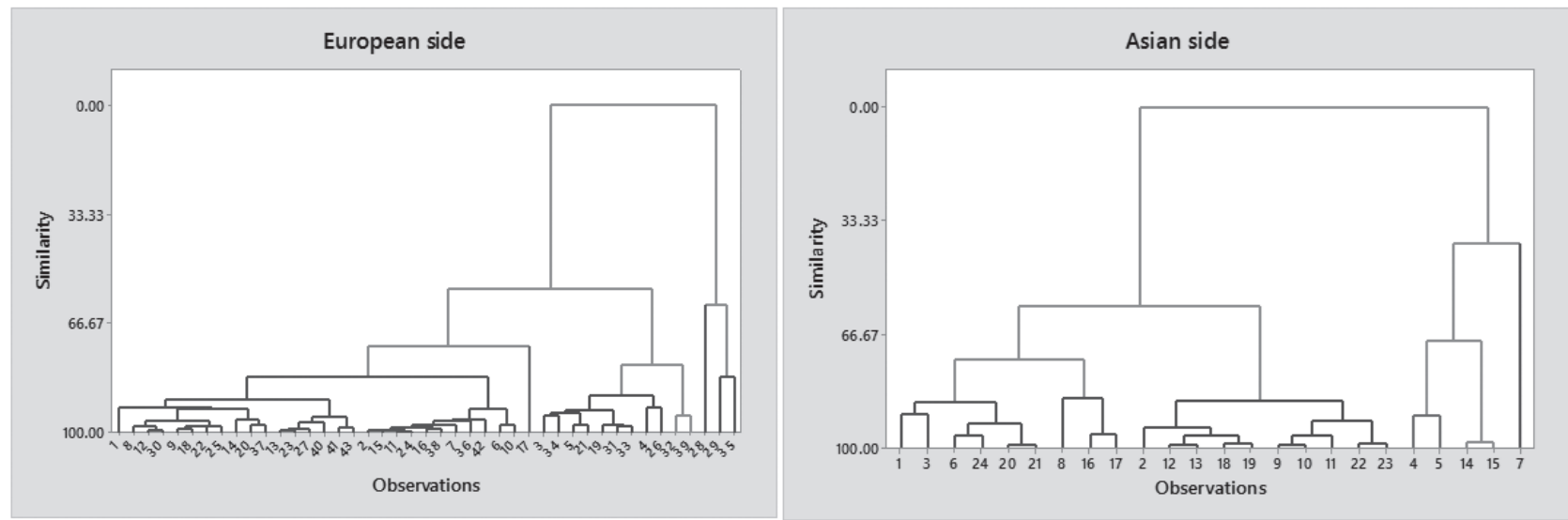

Fig. 3. Cluster analysis for selected metals.

$19 \mathrm{~Bq} / \mathrm{kg}$ for ${ }^{226} \mathrm{Ra}$, from 4 to $21 \mathrm{~Bq} / \mathrm{kg}$ for ${ }^{232} \mathrm{Th}$, and from 359 to $2,742 \mathrm{~Bq} / \mathrm{kg}$ for ${ }^{40} \mathrm{~K}$ on the Asian side (Fig. 2b). The measured activity concentrations of ${ }^{238} \mathrm{U}$, ${ }^{232} \mathrm{Th}$, and ${ }^{40} \mathrm{~K}$ in the moss samples were found under the world average values reported in UNSCEAR 2000 (420, 33 , and $45 \mathrm{~Bq} / \mathrm{kg}$ for ${ }^{40} \mathrm{~K},{ }^{238} \mathrm{U}$, and ${ }^{232} \mathrm{Th}$, respectively) [10].

\section{Metal Deposition on Moss Samples}

Cluster analysis using Minitab 7.0 were applied to investigate and add more meaning to the data acquired through analysis. Six different groups for selected metal concentrations (Al, As, Cd, Cr, Cu, Fe, Hg, Ni, Pb, Sb, V, and $\mathrm{Zn}$ ) were obtained from the Cluster analysis as shown in Figs 3(a-b).

The contamination factor evaluates metal contamination by comparing the metal value in the soil sample to the worldwide value of the metal according to the following equation:

$$
\mathrm{CF}=\mathrm{C}_{\text {sample }} / \mathrm{C}_{\text {reference }}
$$

The enrichment degree of the metal can be classified as follows: no enrichment $(\mathrm{CF} \leq 1)$, minor enrichment $(1<\mathrm{CF} \leq 3)$, moderate enrichment $(3<\mathrm{CF} \leq 5)$, moderately severe enrichment $(5<\mathrm{CF} \leq 10)$, and severe enrichment $(\mathrm{CF}>10)[6,11]$. Fig. 4 shows the contamination factors for

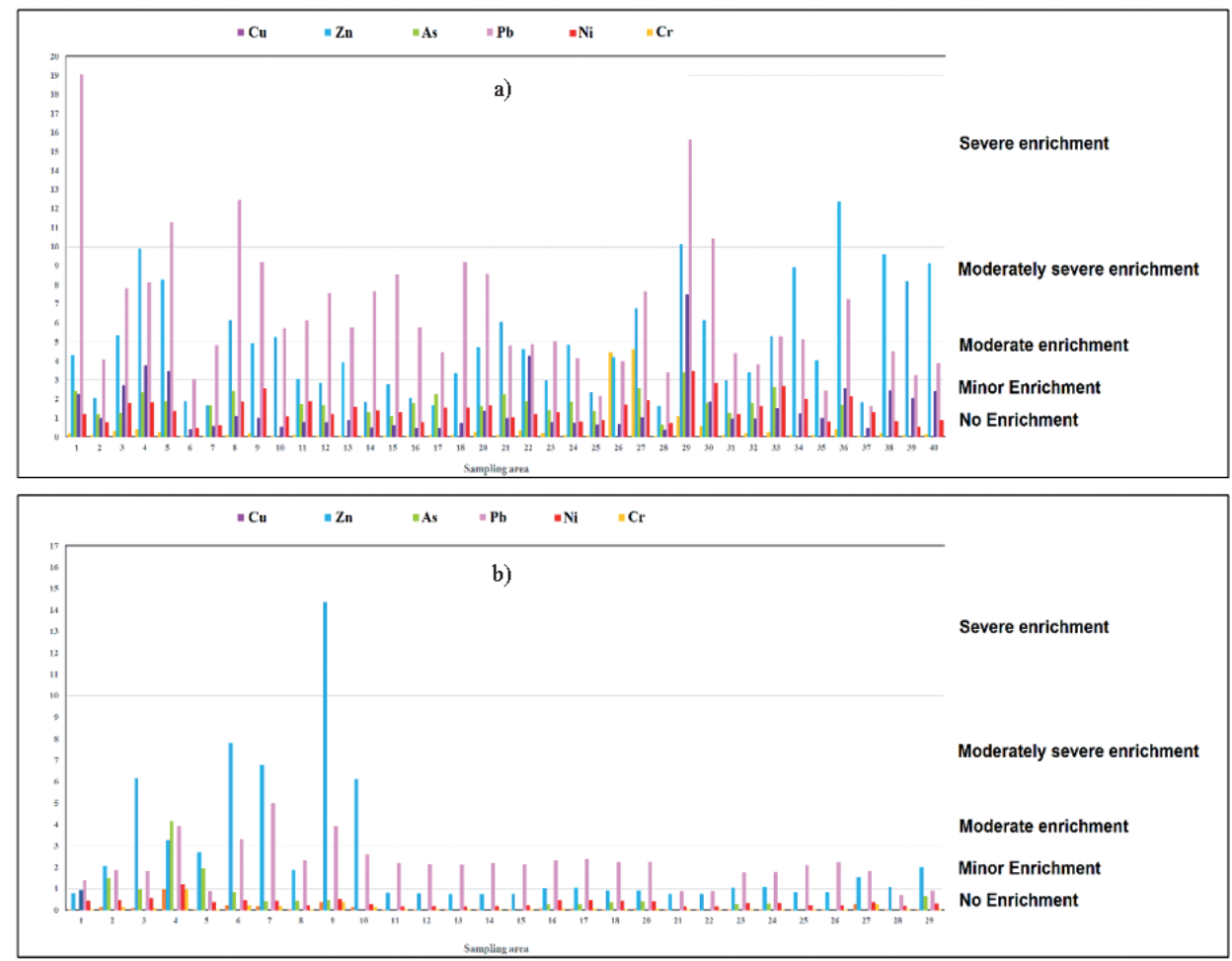

Fig. 4. Contamination factor for a) European and b) Asian sides. 


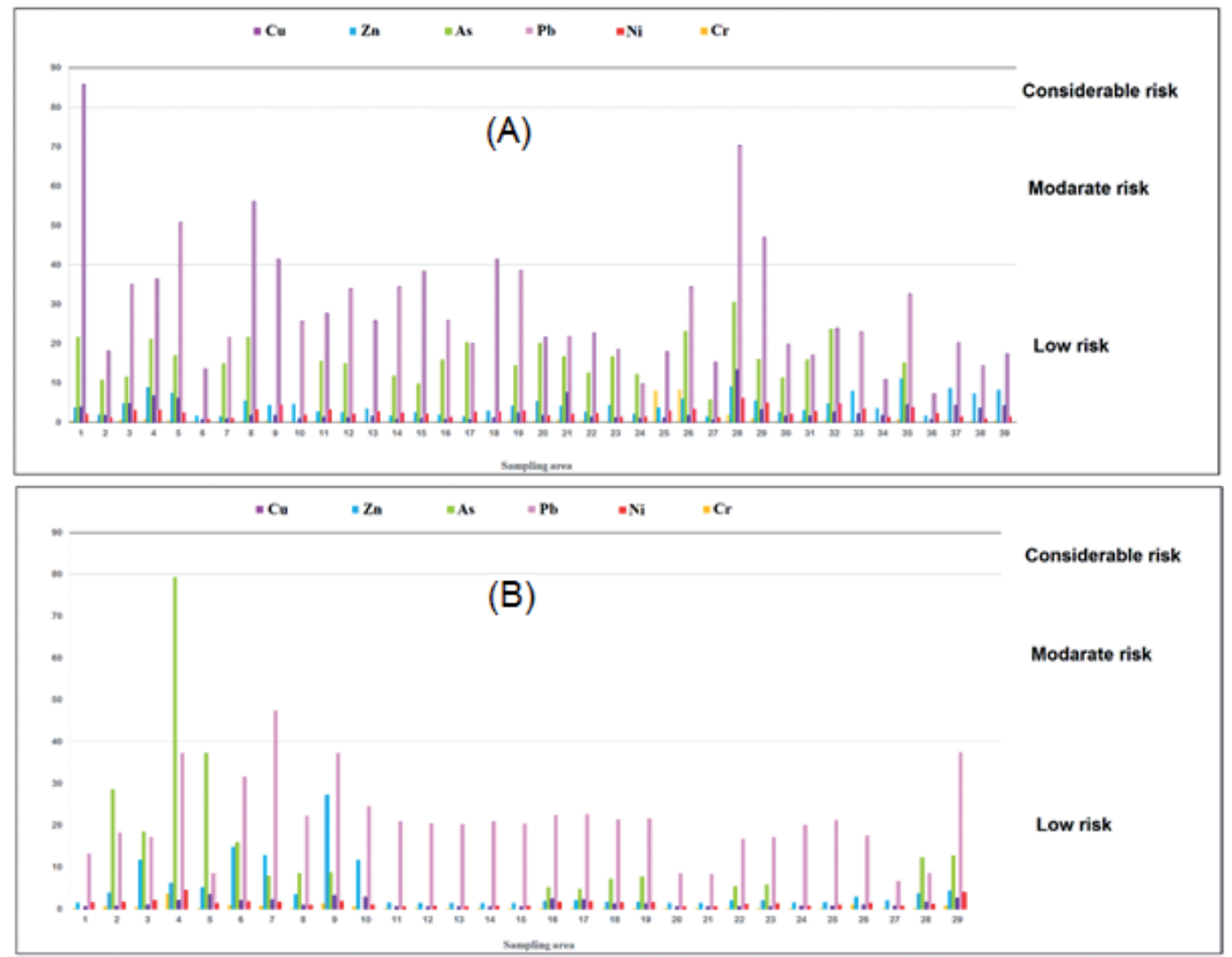

Fig. 5. Potential ecological risk factors for a) European and b) Asian sides.

both sides of Istanbul. The results of the biomonitoring investigations for both sides of Istanbul showed that the elemental concentrations of lead and zinc on the European side and zinc on the Asian side were due to manufacturing industries and road transportation - indicating more severe enrichment than the world average.

The potential ecological risk index (RI) assessed the level of metal pollution according to the toxicity response factor $\left(\mathrm{T}_{\mathrm{ir}}\right)$ of metals such as $\mathrm{Zn}=1<\mathrm{Cr}=2<\mathrm{C}$ $\mathrm{u}=\mathrm{Ni}=\mathrm{Pb}=5<\mathrm{As}=10<\mathrm{Cd}=30$ in the soil $[5,7]$. The RI is calculated as follows:

$$
\begin{aligned}
& \mathrm{F}_{\mathrm{i}}=\mathrm{C}_{\mathrm{s}} / \mathrm{C}_{\mathrm{r}} \\
& \mathrm{E}_{\mathrm{ir}}=\mathrm{T}_{\mathrm{ir}} \times \mathrm{F}_{\mathrm{i}} \\
& \mathrm{RI}=\sum_{\mathrm{i}=1}^{\mathrm{n}} \mathrm{E}_{\mathrm{ir}}
\end{aligned}
$$

...where $\mathrm{F}_{\mathrm{i}}$ is the single metal pollution index, $\mathrm{C}_{\mathrm{s}}$ is the concentration of metal in the samples, $\mathrm{C}_{\mathrm{r}}$ is the reference value for the metal, $\mathrm{E}_{\mathrm{ir}}$ is the monomial potential ecological risk factor, and $\mathrm{T}_{\mathrm{ir}}$ is the metal toxic response factor. The results show that the high lead concentrations indicating a moderate risk level due to road transportation pose a serious problem on both Euro-pean and Asian sides in relation to the heavy vehicular traffic shown in Fig. 5. Only one side has high arsenic concentration due to metal and manufacturing industries.

\section{Conclusions}

The present study aimed to evaluate the radionuclides and potentially toxic element concentrations in the moss samples of the two sides of Istanbul, and to provide background information for future moss biomonitoring for radiological and chemical air pollution studies in Istanbul.

1) Moss samples were analyzed by gamma spectroscopy with respect to ${ }^{238} \mathrm{U},{ }^{232} \mathrm{Th}$, and ${ }^{40} \mathrm{~K}$, and their measured average activity concentrations were within global averages.

2) The enrichment factor was separately calculated for both sides of Istanbul. For the European side it was higher than 10 for $\mathrm{Pb}$, which indicated severe enrichment. The enrichment degree for the Asian side was below 10 for $\mathrm{Pb}$ and $\mathrm{Zn}$, which reflects moderately severe enrichment.

3) The indices of potential ecological risk were found in the following order $\mathrm{Pb}>\mathrm{As}>\mathrm{Zn}$ for both sides. The ecological risk assessment results showed that $\mathrm{Pb}$ and As were the only metals posing a potentially high risk to the city environment.

The present results aspire to be beneficial for the control and reduction of radionuclide and metal contamination. 


\section{Acknowledgement}

We are thankful to Harry Harmens, Gina Mills and Marina Frontasyeva to support our participation in the UNECE ICP Vegetation.

\section{References}

1. GALHARDI J.A., GARCÍA-TENORIO R., FRANCES I.D., BONOTTO D.M., MARCELLI M.P. Natural radionuclides in lichens, mosses and ferns in a thermal power plant and in an adjacent coal mine area in southern Brazil. Journal of Environmental Radioactivity, 167, 43, 2017.

2. DRAGOVIC S., MIHAILOVICN., GAJICB. Quantification of transfer of ${ }^{238} \mathrm{U},{ }^{226} \mathrm{Ra},{ }^{232} \mathrm{Th},{ }^{40} \mathrm{~K}$ and ${ }^{137} \mathrm{Cs}$ in mosses of a semi-natural ecosystem. Journal of Environmental Radioactivity, 101, 159, 2010.

3. KRMAR M., WATTANAVATEE K., RADNOVIC D., SLIVKA J., BHONGSUWAN T., FRONTASYEVA M.V., PAVLOV S.S. Airborne radionuclides in mosses collected at different latitudes. Journal of Environmental Radioactivity, 117, 45, 2013.

4. BELIVERMIS M., ÇOTUK Y. Radioactivity measurements in moss (Hypnum cupressiforme) and lichen (Cladonia rangiformis) samples collected from Marmara region of Turkey. Journal of Environmental Radioactivity, 101, 945, 2010.

5. CUCUlOVIC A., CUCUlOVIC R., SABOVlJEVIC M., RADENKOVIC M.B., VESELINOVIC D. Arhiv Za Higijenu Rada I Toksikologiju-Archives of Industrial Hygiene and Toxicology. 67 (1), 31, 2016.
6. HACIYAKUPOGLU S., ESEN A.N., ERENTURK S., CAMTAKAN Z., KIZILTAS S., OKKA M., GENCELI M., MERCIMEK M., GENCELI E., YUSAN S., GUR F., OLGEN K., TANBAY T. Determining distribution of heavy metal pollution in terms of ecological risk levels in soil of industrially intensive areas around Istanbul. Toxicological and Environmental Chemistry, 97 (1), 62, 2015.

7. ALGHAMDI M. A. Characteristics and risk assessment of heavy metals in airborne PM10 from a residential area of Northern Jeddah City, Saudi Arabia. Pol. J. Environ. Stud. 25 (3), 939, 2016.

8. LEQUY E., SABY N.P.A. ILYIN I., BOURIN A., SAUVAGE S., LEBLOND S. Spatial analysis of trace elements in a moss bio-monitoring data over France by accounting for source, protocol and environmental parameters. Science of the Total Environment, 590, 602, 2017.

9. ALLAJBEU S., QARRI, F., MARKU, E., BEKTESHI L., IBRO V., FRONTASYEVA M.V., STAFILOV T., LAZO, P. Contamination scale of atmospheric deposition for assessing air quality in Albania evaluated from most toxic heavy metal and moss biomonitoring. Air Quality Atmosphere and Health. 10 (5), 587, 2017.

10. UNSCEAR, 2000. United Nations Scientific Committee on the Effects of Atomic Radiation Sources, Annex B, Exposures from Natural Radiation Sources. New York, 90.

11. HAKANSON L. An ecological risk index for aquatic pollution control. A sedimentological approach. Water Research, 14, 975, 1980. 